\title{
Textual Analysis of Power of the Government of Indonesia and Aceh in the Helsinki MoU
}

\author{
Rosaria Mita Amalia \\ rosaria.mita.amalia@unpad.ac.id \\ Universitas Padjadjaran
}

\begin{abstract}
Ethno-national conflict in Aceh struggling for independence from the Unitary State of the Republic of Indonesia was waged for almost three decades since 1976. The military approach taken by the Government of Indonesia (GOI) for years was unable to bring the conflict to an end. Since then, conflict resolution through diplomatic mechanism was initiated by involving third party mediator. The massive natural disasters, earthquake and the tsunami that hit the region in December 2004 prior to the peace agreement between Government of Indonesia and GAM (Free Aceh Movement). The parties committed to agree the memorandum of understanding which known as Helsinki MoU. This research questions whose party more powerful is, Government of Indonesia or Aceh The question can be answered by using Critical Discourse Analysis as a tool. The linguistics instruments can show power which is dominated or not by one of the parties. Based on the findings in this study, it is confirmed that no one from two parties is more powerful than another. It is shown that the power between GOI and GAM is balanced. In other words, based on the analysis of MOU Helsinki, their position is adequate.
\end{abstract}

Keywords: Discourse analysis, Helsinki MOU, power

\section{Introduction}

Ethnic Conflict in Aceh that wants independence from the Government of the Republic of Indonesia has been going on for decades, precisely since 1976. The military approach has been used by the Government of Indonesia to solve this problem, but in fact the existing conflicts are increasingly tapering and far from resolving. Gerakan Aceh Merdeka (GAM/Free Aceh Movement) is an organization that has a goal for Aceh freedom from the Republic of Indonesia. GAM was led by Hasan di Tiro who had lived in Sweden for almost three decades and was Swedish. Hasan Tiro was the son of the birthplace of Aceh (Tiro Village, Pidie) on September 25, 1925 and died in Banda Aceh, June 3, 2010.

The conflict that has caused thousands of civilian victims to start trying to be resolved diplomatically after the era of the fall of President Soeharto. Negotiations that used third parties as mediators were carried out in 2000 and 2002, which resulted in a ceasefire between the two parties, but the agreement did not last long. A devastating natural disaster in the form of an earthquake followed by a tsunami devastated Aceh in December 2004, where the disaster had been resulting in casualties hundreds of thousands of people accompanied by infrastructure damage that reached billions of rupiah. The disaster eventually led to the awareness of various conflicting parties that without peace and a conducive atmosphere, it was impossible to rebuild Aceh, given the magnitude of the damage caused by the natural disaster. This is what underlies the return of negotiations between GAM and the Indonesian Government.

On February 27, 2005, GAM and the Indonesian government began the negotiation phase in Vantaa, Finland. Former Finnish President Marti Ahtisaari acts as a facilitator. On July 17, 2005, after 25 days of negotiations, the Indonesian negotiating team succeeded in 
reaching a peace agreement with GAM in Vantaa, Helsinki, Finland. Agreements were reached to end the conflict peacefully in the Memorandum of Understanding (MoU) between the Government of Indonesia and GAM signed in Helsinki on 15 August 2005.

The Indonesian Government and the Free Aceh Movement affirm their commitment to resolve the conflict in Aceh respectfully for all parties, with a peaceful, comprehensive and sustainable solution. The parties are determined to create conditions so that the governance of the Acehnese people can be realized through a democratic and fair process within the unitary state and the constitution of the Republic of Indonesia. The parties are very confident that only a peaceful resolution of the conflict will enable the reconstruction of Aceh after the tsunami on December 26, 2004 to achieve progress and success. The parties involved in the conflict are determined to build mutual trust. This Memorandum of Understanding details the contents of the agreement reached and the principles that will guide the transformation process.

Among the important points was that the Indonesian government would help facilitate the formation of local political parties in Aceh and grant amnesty to members GAM. The signing of the peace process is then monitored by a team called the Aceh Monitoring Mission (AMM) which consists of five ASEAN countries and several countries that are members of the European Union.

\section{Literature Review}

\section{Critical Discourse Analysis}

Critical Discourse Analysis (CDA) is an understanding of discourse that is not merely positioned merely as the object of language study, which is an understanding of traditional linguistics, but in the context of language as a tool used for certain purposes and practices, including the practice of ideology.

Quoting the statement from Fairclough which states that (1995: 2), "CDA is consolidated here as a 'three-dimensional' framework where the aim is to map three separates forms of analysis of discourse practice (spoken or writer) language text, analysis of discourse practice (processes of text production, distribution and consumption) and analysis of discursive events as instances of sociocultural practice", it can be analysed that $\mathrm{CDA}$ as a tangible three-dimensional framework in three forms of analysis formed through language texts, discourse practices, and sociocultural practices.

\section{Fairclough Critical Discourse Analysis}

Fairclough sees critical discourse analysis as a "three-dimensional" framework that brings together three different analyzes, namely: textual analysis, analysis of discourse practices (the process of production, distribution, and consumption of the text), and analysis of sociocultural practices. In textual analysis, the things studied are how the structure of the text, processes, and vocabulary are used to bring up certain representations. In the practice of discourse, what is examined is how the process of production, distribution, and consumption of the text. While in the analysis of sociocultural practices, the things studied are dimensions that relate to contexts outside the text, such as situation, institution, and social. In this paper, the author only focuses the form of power raised between GAM and Indonesian Government in the Helsinki MOU through textual analysis.

\section{Text Dimension}

Text analysis includes analysis of vocabulary, semantics or meaning, structure and also the smallest elements of each sentence. Fairclough states that, "the analysis of texts covers traditional forms of linguistic analysis-analysis of vocabulary, semantics, the grammar of 
sentences and smaller units, and the sound of system (phonology) and writing system. But it also includes the analysis of textual organizations above the sentence, including ways to connect together ('cohesion'), and things like organization of turn-taking in interviews or the overall structure of a newspaper article "(1995: 57).

\section{Power of Attorney}

Discourse in the form of text is not seen as something natural, and neutral, but it is a form of struggle for power. Fairclough (1995: 1) states that "the power is conceptualized between participants in discourse events, and in terms of capacity to control how texts are henceforth the shapes of texts in sociocultural particular contexts."

\section{Identity}

The identity of the Indonesian Government in the Helsinki MoU is an official representation of the Unitary State of the Republic of Indonesia, in other words the Indonesian Government is seen as something that is integrated with the Negara Kesatuan Republik Indonesia/NKRI (Unitary States of Government of Indonesia). Aceh's identity in this MoU is represented by the Aceh Government (Legislative), Acehnese People, and GAM. While Indonesian Government is only represented by Government of Indonesia. Fairclough stated that "language use is always simultaneous constitutive of (i) social identities, (ii) social relations, and (iii) systems of knowledge and belief-though with different degrees of salience in different cases (1995: 131)."

\section{Results and Discussion}

The Memorandum of Understanding (Helsinki MOU) between the Government of Indonesia and GAM consists of 6 topics/ themes namely: Implementation of Government in Aceh, Human Rights, Amnesty and Reintegration into Communities, Security Arrangement, Establishment of the Aceh Monitoring Mission, and Settlement of Disputes. Each theme of the text produces sub-themes which are details of each problem raised. The prominent actors from the sentences raised are Aceh (Aceh Government), the Government of Indonesia, GAM, the Acehnese People and the AMM (Aceh Monitoring Mission. AMM is a team formed based on an agreement between the Government of the Republic of Indonesia and GAM (Free Aceh Movement) signed in Helsinki, Finland on 15 August 2005 and on duty starting 15 September.

From the preamble of MoU, it is obvious that both parties have been concerned with the humanitarian aspect of the Acehnese after the disaster of the earthquake and tsunami. Kingsbury stated that the peace agreement in Aceh strongly triggered by the disaster of the tsunami which grounded the conflicting parties to the moral base. The shortcoming of the Indonesian government to cope with the disaster and the suffering of Acehnese from armed conflict and the tsunami is a great concern of both parties. (Kingsbury, 2007 in Ulya, 2014).

One thing can be observed is the opening sentence of the MOU, in which the subject relates to Government of Indonesia and GAM.

(1) "The government of Indonesia (GoI) and the free Aceh Movement (GAM) confirm their commitment to a peaceful, comprehensive and sustainable solution to the conflict in Aceh with dignity for all. The parties commit themselves to creating conditions within which the government of the Acehnese people can be manifested through a fair and democratic process within the unitary state and constitution of the republic of Indonesia. The parties are deeply convinced that only the peaceful 
settlement of the conflict will enable the rebuilding of Aceh after the tsunami disaster on 26 December 2004 to progress and succeed".

Both actors have the same role and this is characterized by the existence of "and" conjunctions that function as enhancers of information, without giving more power to one party. The form of power can also be seen in the selection of words such as verb commit and noun commitments (the words used are still in the opening of this MOU). These words are inherent and binding on both parties, both the Government of Indonesia and GAM, for example in the following sentence:

(2) The parties commit themselves to ...

(3) The parties to the conflict commit themselves to ...

It can be said that the power of both parties is balanced. Henceforth let's look at the power that is in the sentences listed in each article.

\section{Article 1:}

Implementation of Government in Aceh with a sub-theme containing the Law on the Implementation of Government in Aceh, Participation in Politics, Economics and Legislation.

In this article, which emphasizes the administration of government in Aceh, the prominent subject is Aceh. The interesting thing is, for almost every sentence, the subject complements appeared refer to the actor which is the Government of Indonesia. The examples of the sentences are:

(4)" Aceh will exercise authority within all sectors of public affairs, which will be administered in ..., except in the fields of foreign affairs, external defence, ... which belong to the Government of the Republic of Indonesia in conformity with the Constitution.

(5) "International agreements entered into by the Government of Indonesia which relate to matters of special interest to Aceh will be entered into in consultation with and with the consent of legislature of Aceh.

In the fifth sentence, the actor raised is the Indonesian Government, but it turns out that the Indonesian Government does not have full power to act, because there must still be an agreement from Aceh Legislature. In this article with the sub-theme of the Law concerning the Implementation of Government in Aceh, there is only one sentence which states the full authority of Aceh, namely in sentence (6) "Aceh has the right to use regional symbols including a flag, a crest, and a hymn. Balanced power is raised in the legislation sub-theme, although the prominent subject is Aceh, but the Government of Indonesia is also represented as a power balancer, seen in (7) "An independent and impartial court system, including a court of appeals, will be established for Aceh within the judicial system of the Republic of Indonesia."

\section{Article 2:}

Human Rights. In this article, more power is given to Aceh with the commitment of the Indonesian Government to comply with the United Nations International Convention on civil and political rights regarding economic, social and cultural rights. In addition, other sentences are made in a passive form so that the actor is not considered important.

\section{Article 3:}

Amnesty and Reintegration into the Community. In this article, a balanced power between the Government of Indonesia and Aceh appears in a sentence that shows the equality 
between the two, such as the Government of Indonesia will give amnesty to all people involved in GAM activities. On the other hand, GAM members who still use weapons after the signing will be considered as violations and can result in the cancellation of amnesty.

\section{Article 4:}

Security arrangements. In this section, balanced power is quite clear from some statements regarding the Government of Indonesia and GAM, (8) All parties will end up signing the MOU, (9) GAM undertakes to demobilize all of its 3000 military troops, (10) Government of Indonesia will withdraw all elements of non-organic police forces from Aceh.

\section{Article 5:}

Establishment of the Aceh Monitoring Mission (AMM). The role of the AMM as a third party agreed upon by the two parties as monitoring institutions is sufficiently highlighted in this section. It starts with an explanation and tasks specifically specified regarding the resolution of the conflict which places the Government of Indonesia and Aceh to the same degree, so that there is no more power from both sides. The sentence (11) shows that "An Aceh Monitoring Mission (AMM) will be established by the European Union and the ASEAN contributing countries with mandate to monitor the implementation of the parties in Memorandum of Understanding."

\section{Article 6:}

Settlement of disputes. Balanced power is proven again in this article, in which case the resolution of the dispute will be resolved by the Head of Mission Monitoring through deliberations with the parties and all parties provide the required information as soon as possible. If no agreement is reached there will be a settlement by inviting senior representatives from each party. This statement shows the absence of certain parties, both the Indonesian and Aceh Governments whose interests are prioritized or given more power.

\section{Conclusion}

Based on textual analysis that refers to the prominence of actors, lexical/diction choices and sentence structure in the Helsinki MOU, it can be stated that the power that emerged between the Government of Indonesia and Aceh is quite balanced so that no party is more dominant than the others. It is expected that agreements that have been negotiated upon by both parties can be carried out so as to create peace on in Aceh. Even in textual analysis, the power of both parties analyzed has no domination, but for real political perspective, it can be said that by giving more independence chance to Aceh, the Government of Indonesia has unity benefit because Aceh can be maintained as part of the Unitary State of the Republic of Indonesia (NKRI). For political agreement, this condition gives power to Indonesia as a country and it gives creates value to Indonesian to the world. The unity can muffle the internal conflict which can be imitated by the same cases in different region in Indonesia and also the world.

\section{References}

. 1995. Critical Discourse Analysis: The Critical Study of Language. England: Longman Group Limited.

Eriyanto. 2001. Analisis Wacana: Pengantar Analisis Teks Media. Yogyakarta: LKiS.

Fairclough, Norman. 1989. Language and Power. USA: Longman Inc.

Holsti, K.J. 1992. Politik Internasional:Suatu Kerangka Analisis (Terjemahan). Bandung: Bina Cipta. 
http://www.aceh-mm.org/download/english/Helsinki\%20MoU.pdf.

https://media.neliti.com/media/publications/108495-ID-refleksi-memorandum-ofunderstanding-mou.pdf.

https://media.neliti.com/media/publications/26315-EN-negotiating-aceh-selfdetermination-in-indonesias-unitary-system-a-study-on-peac.pdf, December 2012 ISSN: 2088-9976.

Jorgensen, Marianne\& Philips, Louise. 2002. Discourse Analysis as Theory and Method. London: Sage Publications Ltd.

Kadir, M.Y. Aiyub. 2012. "Negotiating Aceh Self-Determination in Indonesia's Unitary System: A Study on Peace Agreement Helsinki Memorandum of Understanding 2005". Aceh International Journal of Social Sciences, 1 (2): 63-76

Kingsburry, D., 2005. A Mechanism to end conflict in Aceh, Security Challenge, Vol. 1, No. 1, p.47.

Kingsbury, D. 2007. Peace Processes in Aceh and Sri Lanka: A Comparative Assessment, Security Challenge, Vol. 3, No. 2, p. 23.

Ulya, Zaki. 2014. Refleksi Memorandum of Understanding (MoU) Helsinki Dalam Kaitan Makna Otonomi Khusus Di Aceh. Jurnal Konstitusi, Volume 11, Nomor 2, Juni 2014.

Wodak, Ruth dan Meyer, Michael. 2001. Methods of Critical Discourse Analysis. London: Sage Publication.

Zaki, Muhammad. 2011. Natural Disasters and Ethno National Conflict Resolution: The study of ripeness in Aceh-Indonesia conflict resolution (Unpublished thesis). USA: Arcadia University. 